\title{
Early stage litter decomposition rates for Swiss forests
}

\author{
ALEXANDER HEIM ${ }^{1,2, *}$ and BEAT FREY ${ }^{1}$ \\ ${ }^{1}$ Swiss Federal Institute for Forest Snow and Landscape Research WSL, Zürcherstr, 111, CH 8903 \\ Birmensdorf, Switzerland; ${ }^{2}$ Current address: Physical Geography, Department of Geography, University \\ of Zurich, Winterthurerstr.190, CH 8057 Zürich, Switzerland; *Author for correspondence (e-mail: \\ alexheim@geo.unizh.ch; phone: +41-1-63-55-183; fax: +41-1-63-56-848)
}

Received 26 June 2003; accepted in revised form 20 November 2003

Key words: Carbon cycle, Forest ecosystem monitoring, Litter decomposition, Litterbags

\begin{abstract}
The decomposition of belowground and aboveground tree litter was studied on five forest sites across Switzerland, ranging from 480 to $1500 \mathrm{~m}$ in altitude, and including calcareous and acidic soils. In addition to decomposition of local litter types (Picea abies, Fagus sylvatica, Castanea sativa), the decomposition of a standard beech litter was studied on all sites. After 2 years of decomposition, mass loss ranged from 18 to $71 \%$ across the different sites and litter types. The lowest decomposition rates were observed for beech roots, while mass loss was greatest for both spruce needles and spruce roots at the low-altitude site. Mass loss during the first winter correlated best with the content of watersoluble substances. After 1 year of incubation, mass loss of the standard litter varied less than did mass loss of local litter, but variance increased during the second year for aboveground litter. These observations indicate a smaller climatic influence on litter breakdown at the beginning of the decomposition process. Litter mass loss could be described using an exponential model with a decay constant depending on either lignin/ $\mathrm{N}$ ratio or $\mathrm{Mn}$ content of the litter and annual soil temperature and throughfall precipitation as climatic variables. Modelling the observed mass loss indicated a strong influence of litter quality in the first 2 years of decomposition, confirming the field data from the standard litter experiment. The experiment will continue for some years and is expected to yield additional data on long-term decomposition.
\end{abstract}

\section{Introduction}

Litter decomposition is an important process in the global $\mathrm{C}$ cycle as it returns $\mathrm{C}$ that was previously fixed in terrestrial biomass to the atmosphere. The rate at which litter is decomposed and mineralised depends on a variety of environmental parameters, the most important of which are litter quality and climate (Berg et al. 2000). Rising atmospheric $\mathrm{CO}_{2}$ concentrations and changing temperatures have stimulated research on the global $\mathrm{C}$ cycle and numerous models have been developed in order to predict $\mathrm{C}$ storage in various ecosystem compartments and fluxes between them (for a review, see Perruchoud and Fischlin (1995)).

In global or regional models of $\mathrm{C}$ cycling, decomposition rates (among other data) are important input parameters. Such rates have been published for North American and Scandinavian boreal forests, for example, Berg (2000). Trofymow et al. (1995) used several models from the literature to predict litter decomposition rates for a wide variety of litter types used in the Canadian Intersite Decomposition 
Experiment (CIDET). Results after 3 years of decomposition (Moore et al. 1999) showed that lignin/ $\mathrm{N}$ ratio, mean annual temperature and mean precipitation were valuable parameters for predicting mass loss. Six-year data (Trofymow et al. 2002) emphasised the dominance of climatic conditions over litter quality parameters in determining mass loss. Berg and co-workers used a standard litter type incubated at various sites to separate effects of climate and litter quality (Berg et al. 1993, 1998). In a study restricted to Norway spruce litter, Berg et al. (2000) observed that needle litter degradation along a transect of Norway spruce forests depended on $\mathrm{Mn}$ content in needles. For some litter types, decomposition rates were observed to approach zero (Berg and Ekbohm 1991; Howard and Howard 1974). As a result, mass loss reached a final value below $100 \%$, leaving an apparently undegradable litter fraction. A synthesis of long-term decomposition studies in various forest ecosystems revealed relationships between initial $\mathrm{N}$ and Mn concentrations in litter and an apparent final limit value of decomposition (Berg et al. 1996). However, the authors concede that the limit value phenomenon might be, at least in part, an experimental artefact caused by the exclusion of larger soil animals from litterbag studies.

In contrast to the variety of data on boreal conifer forests, there are few data available comparing litter decomposition in conifer and deciduous forests under the temperate climate regime of central Europe. As far as we know, no such data have been published for alpine or subalpine regions.

Within the Long-term Forest Ecosystem Research (Langfristige Waldökosystemforschung, LWF) in Switzerland, the effects of natural and anthropogenic factors on ecosystem stability are monitored continuously on 16 permanent monitoring sites covering a wide range of climatic and edaphic factors (Thimonier et al. 2001). On seven sites there is an intensive monitoring of the biogeochemical cycles, including net primary production, litterfall and soil solution chemistry. These integrated monitoring sites present an ideal setting for the present study, as litter decomposition rates complement existing data on element cycling. A wide range of data is available for the development of ecosystem models.

The objectives of the present study were (1) to generate litter mass loss data for typical forest sites in Switzerland, (2) to assess litter quality and identify parameters determining mass loss rates in early stages of litter decomposition, (3) to estimate the relative contribution of climate and litter quality to litter decay, and (4) to develop a simple model that can adequately describe the observed decomposition rates.

\section{Materials and methods}

Sites, chemical analysis of litter material, and litterbag preparation

The experiments were conducted on five long-term monitoring sites of our institute's LWF project. The sites range from 480 to $1500 \mathrm{~m}$ in altitude, tree species include conifers and deciduous trees, and the soils include calcareous and acid soils. Detailed site characteristics and species used for study are given in Table 1. 


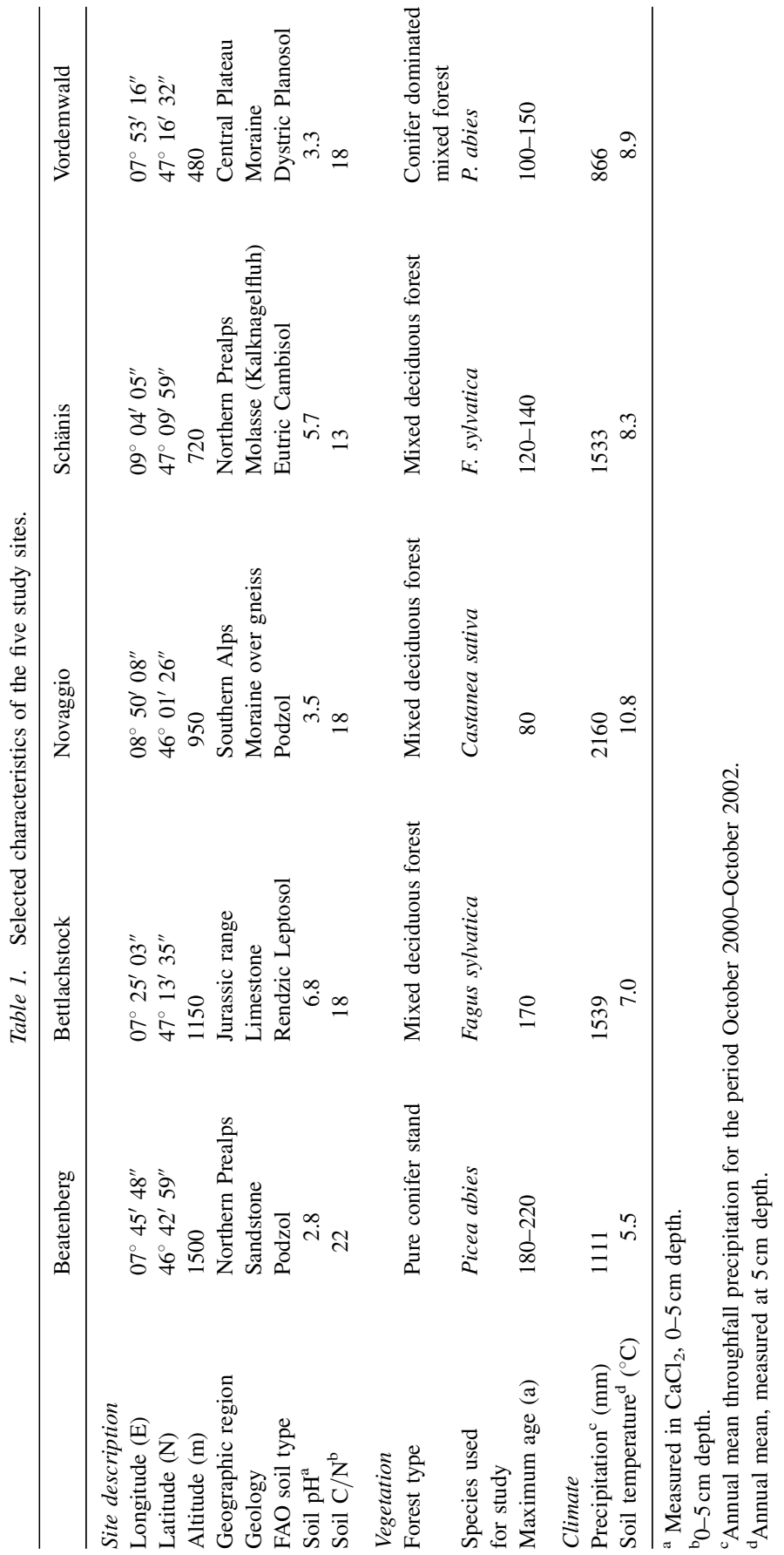


Aboveground and belowground litter of the species studied was collected in autumn 2000. Beech and chestnut litter were collected in nets during litterfall. Spruce needles were collected from felled trees and root litter was dug out from the topsoil and thoroughly washed. All litter types were air dried at $20^{\circ} \mathrm{C}$ and analysed for the following parameters:

Residual water content by drying at $105^{\circ} \mathrm{C}$, ash content by dry ashing at $550{ }^{\circ} \mathrm{C}$ for $4 \mathrm{~h}, \mathrm{C}$ and $\mathrm{N}$ content by $\mathrm{CN}$ analyser (NA2500, Carlo Erba), element contents by ICP-AES (Optima 3000, Perkin Elmer) after microwave digestion in $40 \%$ $\mathrm{HNO}_{3} /$ conc. $\mathrm{HF}$ at $240{ }^{\circ} \mathrm{C}$ and 120 bar (UltraClav, Microwave Laboratory Systems); water extractables by extracting $1 \mathrm{~g}$ of milled sample three times with $25 \mathrm{ml}$ of hot $\left(85 \pm 5^{\circ} \mathrm{C}\right)$ water and once with cold water $(15 \mathrm{~min}$ each); phenolics in the water extracts by the Folin-Denis colorimetric method (Swain and Hillis 1959); Klason lignin by hydrolysing $0.3 \mathrm{~g}$ of pre-extracted (hot water and ethanol) sample with $3 \mathrm{ml}$ of $72 \%$ sulphuric acid $\left(1 \mathrm{~h}\right.$ at $\left.30^{\circ} \mathrm{C}\right)$ and, after addition of $84 \mathrm{ml} \mathrm{H} \mathrm{H}_{2} \mathrm{O}$, autoclaving for $1 \mathrm{~h}$ at $121^{\circ} \mathrm{C}, 0.12 \mathrm{MPa}$; and soluble lignin by $\mathrm{UV}$ absorption $(205 \mathrm{~nm})$ of the hydrolysate (Dence 1992). Total lignin was calculated as the sum of Klason lignin and soluble lignin.

Approximately $1 \mathrm{~g}$ of aboveground or belowground litter was packed into litterbags of $1-\mathrm{mm}$ mesh size $(10 \mathrm{~cm} \times 10 \mathrm{~cm}$, polypropylene $)$. The bags were weighed to the nearest $\mathrm{mg}$ and given unique code numbers. The litterbags used for spruce needles required modification because needle diameter was smaller than $1 \mathrm{~mm}$. Five bags were attached to a UV stable cord and each strand of five bags comprised one composite sample for chemical analysis after harvest. On each of the five sites, four subplots (approx. $5 \mathrm{~m}$ in diameter) were set up. On each subplot, six strands of aboveground litter and six strands of root litter were placed into the topsoil, giving 60 bags per subplot, 240 bags per site and a total of 1200 bags.

Beech leaf and beech root litter from Schänis were used as standard litters and incubated at the other four sites in addition to the local litter types. The same design was used as for local litter, resulting in an additional $4 \times 240=960$ bags. All bags were inserted at the field sites between 24 October and 8 December 2000.

\section{Harvest}

One sixth of the total number of bags was harvested each in spring and autumn of 2001 and 2002, while the rest remains in the field for future sampling. On each of the four subplots one strand of aboveground litterbags and one strand of root litterbags were collected, giving a total of 20 litterbags per litter type. In Novaggio, some bags were lost when wild boar uprooted two of the subplots.

The bags were dried to constant weight at $60^{\circ} \mathrm{C}$, carefully cleaned and weighed and the five samples from each strand were pooled. The pooled samples were milled to pass a $0.5 \mathrm{~mm}$ sieve. A subsample was used to determine residual water and ash content. All mass loss values were corrected for ash and water content and are expressed as ash free dry mass. 
The samples were analysed for the same parameters as the initial litter, with the following exceptions. Elemental concentrations were determined only once (after 1 year) and water extractables and lignin were determined at each sampling date for local litters but only twice (after 1 and 2 years) for the standard litter.

Statistical analysis and model fitting were performed using DataDesk 6.1 for Macintosh.

\section{Results and discussion}

\section{General observations}

Relatively small changes occurred in the visible structure of the litter samples during the 2-year period of the experiment. Fagus roots in particular showed little visible breakdown but still lost part of their original weight. Picea needles showed a similar effect and could still be identified after 2 years of incubation, despite losing more than half of their weight. Leaves most often broke down to small fragments, but there were also some bags from which almost entire leaves could be recovered. This illustrates the high variability that can be encountered in these experiments and indicates some important limitations of this kind of study. With the lack of mechanical breakdown by larger animals there is less surface available for microbiological attack, and decomposition might be retarded (Cortez and Bouche 1998). On the other hand, this experiment, in common with other experiments of this type, clearly shows that substantial degradation can occur in litterbags even in the absence of mechanical breakdown.

\section{Initial material}

Table 2 presents chemical data of the 10 litter types. There were large differences in the variability of these parameters between litter types. Variation between the litter type with the highest concentration and the litter type with the lowest concentration was largest for $\mathrm{Al}$ with a factor of $29, \mathrm{Fe}$ (15) and $\mathrm{Mn}$ (12) and smallest for $\mathrm{C}$ (1.04), lignin (1.65) and $N$ (1.9). The values were within the ranges reported in other studies (Aber et al. 1990; Berg et al. 1996; Moore et al. 1999).

\section{Litter mass loss}

Table 3 presents mass loss, $\mathrm{C}$ loss and $\mathrm{N}$ loss of the 10 litter types during the first and second years. Mass loss during the first year varied between $15 \%$ for beech roots at Bettlachstock and $48 \%$ for spruce needles at Vordemwald. After 2 years, mass loss ranged from 18 to $71 \%$, with beech roots from Bettlachstock still showing the lowest decomposition rate, while the fastest decomposing litter type had changed from spruce needles at Vordemwald (67\% decomposed) to spruce roots at Vordemwald (71\% decomposed). 


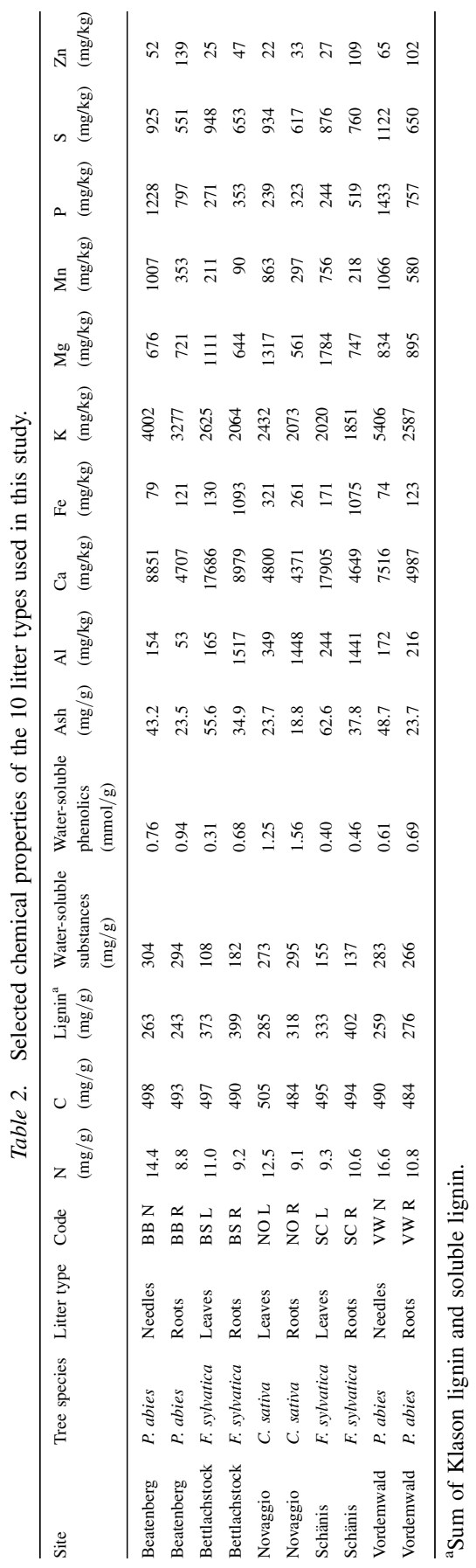




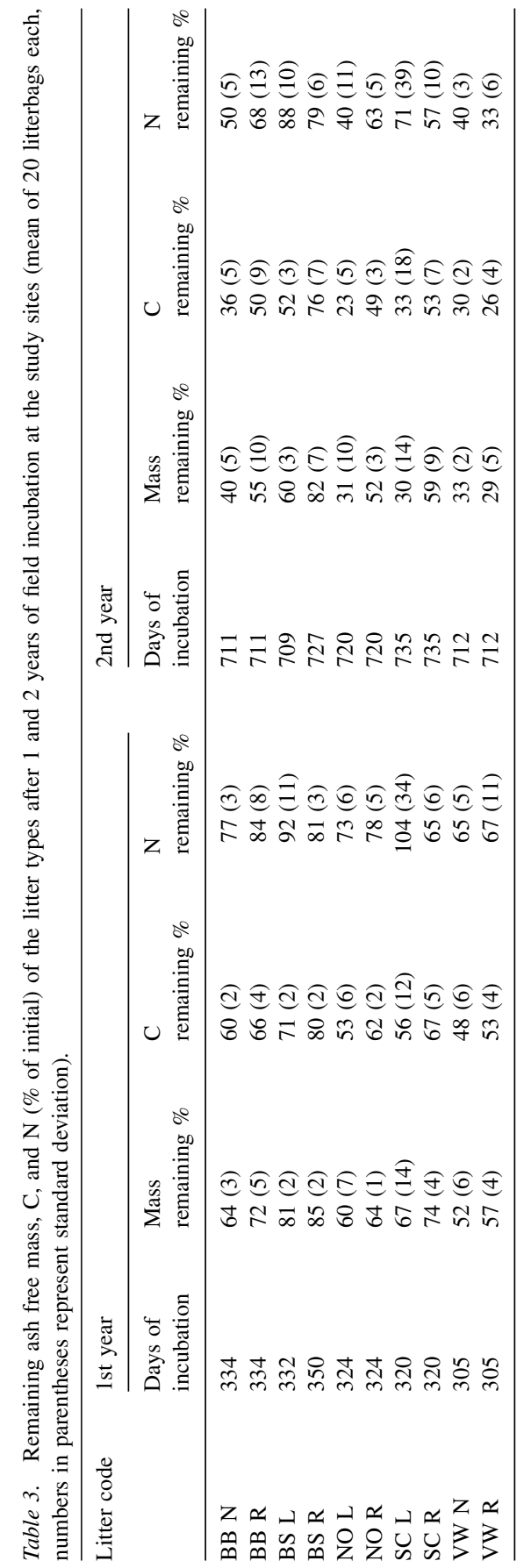




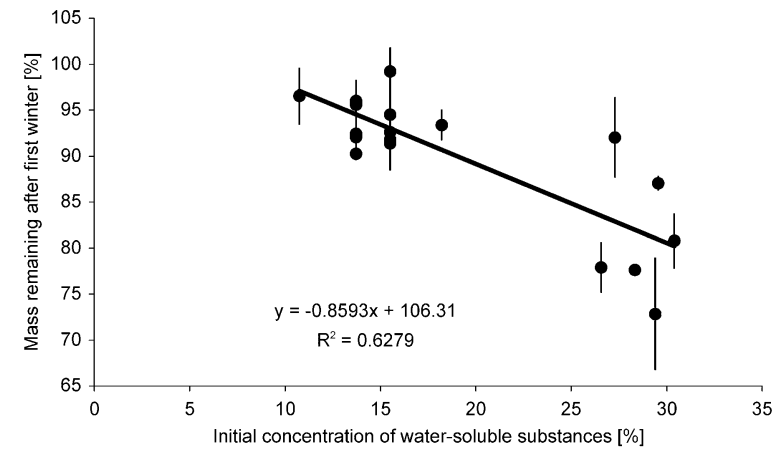

Figure 1. Correlation between mass remaining after first winter (\%) and initial content of water-soluble substances (\%) in the litter (local and standard litters combined). Each circle is the mean of 20 litterbags. Error bars indicate standard deviation.

During the first year, root litter at all sites decomposed more slowly than did the corresponding aboveground litter. After the second year, there was one exception to this pattern: spruce roots at Vordemwald showed a slightly higher mass loss than spruce needles. While beech roots at both Bettlachstock and Schänis decomposed very slowly, beech leaves behaved differently. They decomposed more rapidly at the Schänis site than at Bettlachstock.

Most of the mass loss in the first year occurred during the winter months, especially in the case of the spruce needles. The mass loss during the first winter correlates with the amount of water-soluble substances in the initial litter (Figure 1). Mass loss and $\mathrm{C}$ loss were well correlated, as the $\mathrm{C}$ concentration of the litter did not change greatly. In most litter types, $\mathrm{N}$ was lost at a slower rate than total litter mass, leading to an increase in $\mathrm{N}$ concentration. With increased mass loss in the second year, absolute litter $\mathrm{N}$ decreased in all litter types.

\section{Controls on litter decomposition}

Aerts (1997) emphasised that, within a particular climatic region, litter quality is the best predictor of litter decomposition, although on a global scale climate is the dominant driving factor. In accordance with this, Berg et al. (2000) found litter parameters to be superior to climatic parameters when examining needle litter breakdown along a climatic transect across Scandinavia, whereas this was less evident for root litter (Berg et al. 1998). The present study provides for the first time data on litter decomposition in alpine and pre-alpine forest ecosystems, and in contrast to most of the studies conducted in Scandinavia, also includes deciduous tree species.

In regression analysis with chemical data of initial material, two parameters correlated well with remaining amount after 1 and 2 years, namely lignin/ $\mathrm{N}$ ratio and Mn concentration (Figure 2). There were no significant correlations with other litter quality parameters, including water-soluble phenolics concentration $\left(r^{2}<0.1\right)$ 

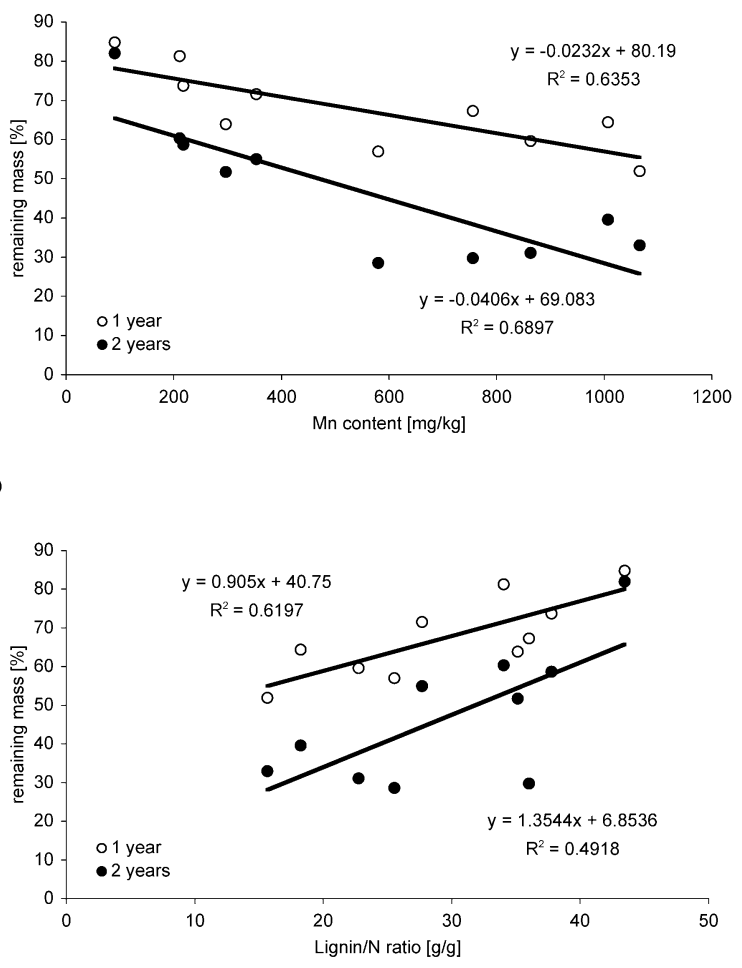

Figure 2. Remaining litter mass of local litters (\%) after 1 and 2 years of decomposition as a function of (a) Mn content $(\mathrm{mg} / \mathrm{kg}$ ) and (b) lignin $/ \mathrm{N}$ ratio $(\mathrm{g} / \mathrm{g})$ of the initial material. Each circle is the mean of 20 litterbags.

or concentration of nutrient elements $\left(r^{2}<0.3\right.$ for all elements tested). A multiple regression analysis including $\mathrm{Mn}$ concentration and lignin/ $\mathrm{N}$ ratio, although explaining the variance slightly better, produced insignificant coefficients and thus could not improve the model. This demonstrates that the dominating factors regulating litter breakdown are the same as those identified elsewhere (Moore et al. 1999; Berg et al. 2000). Most of the variation in first year mass loss can be explained by lignin/ $\mathrm{N}$ ratio or $\mathrm{Mn}$ concentrations of the fresh litter.

Lignin is a major recalcitrant polymer of plant cells and only few organisms are able to degrade it. Among these are white-rot fungi, which secrete extracellular ligninolytic enzymes. This secretion is regulated by Mn concentrations (Perez and Jeffries 1993). While the early steps of lignin breakdown are catalysed by manganese peroxidase $(\mathrm{MnP})$ expressed under high $\mathrm{Mn}$ conditions, the later stages of lignin decomposition are catalysed by lignin peroxidase (LiP), which is more efficient at low Mn concentrations (Perez and Jeffries 1992). Recently, Chen et al. 


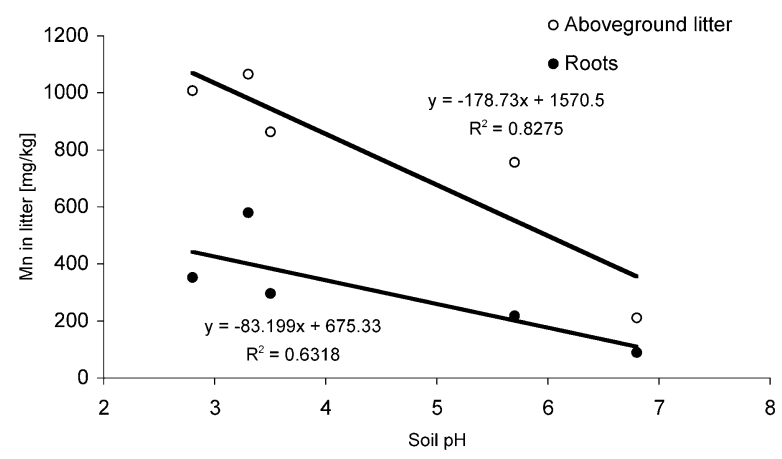

Figure 3. Effects of soil $\mathrm{pH}$ on aboveground and belowground initial litter $\mathrm{Mn}$ content $(\mathrm{mg} / \mathrm{kg}$ )

(2001) demonstrated that $\mathrm{LiP}$ and MnP genes are not restricted to white-rot fungi, but also occur frequently in ectomycorrhizal fungi. As a consequence, these ligninolytic enzymes may be more abundant than previously expected, and the regulative function of Mn can be expected to be a general mechanism. Mn content in the fresh litter itself depended on soil $\mathrm{pH}$ rather than on total Mn content in the soils. This relationship was found to be stronger for aboveground than for belowground litter (Figure 3) and, if generally applicable, would indicate that enzymatic lignin breakdown becomes faster when soil $\mathrm{pH}$ decreases. This may at first seem contradictory to the common observation that acid forest soils can accumulate thick organic layers (Scheffer 2002). However, the increase in faunal activity with soil $\mathrm{pH}$ (Lee 1985) in less acidic and neutral soils could be a possible explanation. If the increase in faunal activity exceeds the decrease in enzymatic lignin breakdown, a net increase in decomposition rate will result which, however, is not reflected in litterbag data recording mainly microbial degradation processes.

In addition to the effects of lignin/ $\mathrm{N}$ and $\mathrm{Mn}$ on medium- and long-term litter decomposition, we observed a very rapid first phase when the content of watersoluble substances determined the extent of mass loss (see above and Figure 1). This occurred during the winter months following litterfall and was most likely an abiotic leaching process as temperatures were low during this period and did not correlate with mass loss (data not shown). Besides litter quality, climate influences litter decomposition. The combined effects of several factors on the decomposition process can be illustrated best by designing a mathematical model. Parameters that significantly increase the predictive power of such a model are considered key variables controlling the process. While it may not be justified to use such a model for the extrapolation of 2-year data to longer time periods, the model is useful to understand and describe the decomposition during the experimental period itself. A major constraint of the regression models presented above is the absence of a time variable. As litter decomposes, its quality changes and its amount is reduced, both of which will affect the decomposition rate in the following years. It is therefore desirable to describe the time course of decomposition, which is usually done using negative exponential functions. The decay constant $k$ is designed as a function of 


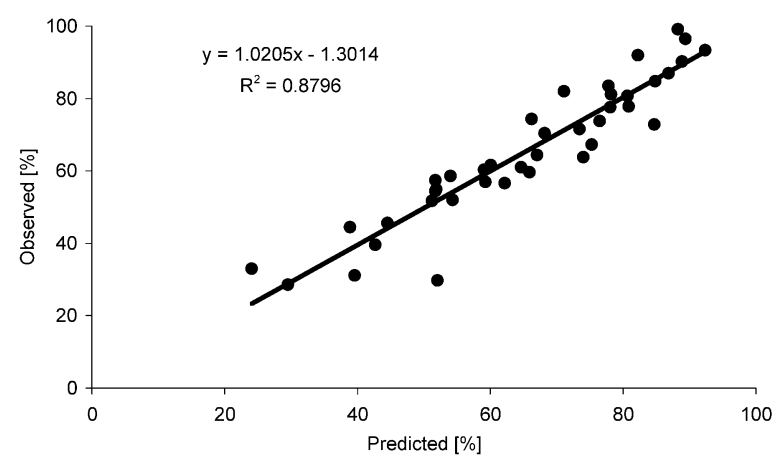

Figure 4. Observed values of remaining litter mass (\%) during the first 2 years versus values predicted by an exponential model using lignin/ $\mathrm{N}$, mean soil temperature and throughfall precipitation as predictors. Data include means of the 10 local litter types for all four sampling dates.

Table 4. Calculated decay constants of the litter types during the first 2 years assuming simple exponential decay (cf. Figure 4).

\begin{tabular}{llll}
\hline Site & Species & $\begin{array}{l}\text { Root litter } \\
k\left(\mathrm{a}^{-1}\right)\end{array}$ & $\begin{array}{l}\text { Aboveground litter } \\
k\left(\mathrm{a}^{-1}\right)\end{array}$ \\
\hline Beatenberg & P. abies & 0.337 & 0.437 \\
Bettlachstock & F. sylvatica & 0.172 & 0.271 \\
Novaggio & C. sativa & 0.339 & 0.470 \\
Schänis & F. sylvatica & 0.306 & 0.325 \\
Vordemwald & P. abies & 0.626 & 0.730 \\
\hline
\end{tabular}

one or more factors controlling decomposition, as shown by Melillo et al. (1982) for the lignin/ $\mathrm{N}$ ratio.

The best model that could be fitted to our dataset includes a decay constant that is a function of one litter quality and two climatic variables:

$$
k=c_{1}+c_{2}(\operatorname{lignin} / \mathrm{N})+c_{3}\left(T_{\text {soil }}\right)+c_{4}\left(P_{\mathrm{TF}}\right)
$$

where $T_{\text {soil }}$ is the mean annual soil temperature and $P_{\mathrm{TF}}$ is the throughfall precipitation. When this model is fitted to the decomposition data of the four sampling dates within the first 2 years, it explains $88 \%$ of the variation in remaining mass during this time period (Figure 4). For the dataset in this study, the best fit was reached for $c_{1}=0.547 \quad(0.115) \mathrm{a}^{-1}, \quad c_{2}=-0.0106 \quad(0.0027) \mathrm{a}^{-1}, \quad c_{3}=0.0600$ $(0.0139){ }^{\circ} \mathrm{C}^{-1} \mathrm{a}^{-1}, \mathrm{c}_{4}=-0.000213(0.000061) \mathrm{mm}^{-1} \mathrm{a}^{-1}$. Values in parentheses are standard errors of the coefficients. Decay constants for the various litter types calculated with this function are presented in Table 4.

\section{Standard and local litter decomposition}

At the Beatenberg and Vordemwald sites, local P. abies roots decomposed faster than F. sylvatica roots. The same was true for the needles of $P$. abies at Beatenberg 
Table 5. Mass loss of the local litter types relative to mass loss of standard litter incubated at the same site. Beech leaves and roots from Schänis were used as standard litter. For comparison, relative lignin/N ratios (local litter/standard litter) are given on the right.

\begin{tabular}{|c|c|c|c|c|c|}
\hline \multirow[b]{2}{*}{ Site } & \multicolumn{4}{|c|}{ Relative mass loss (\%) } & \multirow{2}{*}{$\begin{array}{l}\text { Lignin/N }(\%) \\
\text { initial material }\end{array}$} \\
\hline & 1st sampling & 2nd sampling & 3rd sampling & 4th sampling & \\
\hline \multicolumn{6}{|l|}{ Beatenberg } \\
\hline Aboveground & 351 & 134 & 155 & 117 & 51 \\
\hline Roots & 359 & 219 & 229 & 152 & 73 \\
\hline \multicolumn{6}{|l|}{ Bettlachstock } \\
\hline Aboveground & 47 & 78 & 86 & 82 & 95 \\
\hline Roots & 84 & 68 & 68 & 82 & 115 \\
\hline \multicolumn{6}{|l|}{ Novaggio } \\
\hline Aboveground & 97 & 118 & 110 & 138 & 63 \\
\hline Roots & 294 & 194 & 171 & 141 & 93 \\
\hline \multicolumn{6}{|l|}{ Schänis } \\
\hline Aboveground & 100 & 100 & 100 & 100 & 100 \\
\hline Roots & 100 & 100 & 100 & 100 & 100 \\
\hline \multicolumn{6}{|l|}{ Vordemwald } \\
\hline Aboveground & 259 & 121 & 109 & 94 & 43 \\
\hline Roots & 554 & 222 & 265 & 180 & 68 \\
\hline
\end{tabular}

Table 6. Minimum and maximum remaining litter mass observed at the five sites at four sampling dates within 2 years. The range is given as an indicator of the variability between sites.

\begin{tabular}{llll}
\hline Litter type & Min $(\%)$ & Max $(\%)$ & Range \\
\hline Spring 2001 & & & \\
Local aboveground & 78 & 99 & 21 \\
Local roots & 73 & 93 & 20 \\
Standard leaves & 91 & 99 & 8 \\
Standard roots & 90 & 96 & 6 \\
Autumn 2001 & & & \\
Local aboveground & 52 & 81 & 29 \\
Local roots & 57 & 85 & 28 \\
Standard leaves & 60 & 76 & 16 \\
Standard roots & 74 & 87 & 13 \\
Spring 2002 & & & \\
Local aboveground & 45 & 70 & 25 \\
Local roots & 46 & 84 & 38 \\
Standard leaves & 49 & 73 & 24 \\
Standard roots & 74 & 83 & 9 \\
Autumn 2002 & & & \\
Local aboveground & 30 & 60 & 30 \\
Local roots & 29 & 82 & 53 \\
Standard leaves & 29 & 52 & 19 \\
Standard roots & 59 & 78 & \\
\hline & & & \\
\hline
\end{tabular}


while local needles at Vordemwald decomposed approximately at the same rate as did F. sylvatica leaves. Although belonging to the same species, leaves and roots of F. sylvatica at Bettlachstock generally decomposed more slowly than the standard material originating from Schänis. These observations are linked to the lignin $/ \mathrm{N}$ ratio of the litter types. At a given site, the litter type with higher initial lignin/N ratio usually decomposed more slowly (Table 5).

After half a year of decomposition, the standard litter incubated at the five sites had lost between $1 \%$ and $10 \%$ of its ash-free dry mass, while mass loss of the local litters ranged from 1 to $27 \%$ (Table 6). This tendency towards greater variability in mass loss of local litters continued during the first 2 years, especially for roots. Variability of aboveground litter mass loss became similar between local and standard litter after 2 years.

Such a comparison of local litter with standard litter allows us to estimate the relative importance of site characteristics and litter characteristics on decomposition rates. While mass loss of the various local litter types depends on litter quality and site characteristics, mass loss of the standard litter incubated at different sites is only controlled by site characteristics. As, in the present study, local litter varied more strongly than standard litter (Table 6), it can be concluded that litter quality factors dominated decomposition during the first 2 years. It is, however, possible that the climatic influence increases with time. This could manifest itself by an increasing variability of standard litter mass loss and a correlation with mass loss of local litters. During the late stages of decomposition, however, the direct influence of climate on decomposition is reported to vanish (Berg and Meentemeyer 2002).

These results on the importance of litter quality are confirmed by a detailed examination of the models used for the description of local litter decomposition. In the section on controls on decomposition, we have shown that the litter quality parameters lignin/ $\mathrm{N}$ and $\mathrm{Mn}$ on their own usually explain most of the variance in mass loss. Climate variables, however, cannot be used as sole predictors of mass loss although they improve the predictive power when included into an exponential decay model. Thus, the importance of litter quality could be assessed by two different and independent approaches - the modelling of the local litter data with litter quality variables and a field experiment with standard litter incubated at all experimental sites.

\section{Conclusions}

Litterbag experiments like the present study can give a good description of microbial decomposer activity. The use of standard litter in addition to local litter allows estimating the relative importance of litter quality parameters and site characteristics on decomposition during the sampling period.

The present study confirmed that the factors governing litter decomposition are the same as those identified in previous studies (lignin/N, Mn, temperature, precipitation). It presents a first dataset on decomposition rates valid for alpine and subalpine forests of Switzerland. 
In view of a $\mathrm{C}$ balance, information on long-term decomposition and decay rates of slowly degrading litter pools is highly desirable. The design of this project allows sampling of litterbags at later decomposition stages.

\section{Acknowledgments}

The study was partly funded by the Swiss Agency for the Environment, Forests and Landscape (SAEFL), Grant No. 810.3189.06. We thank the team of our central laboratory for $\mathrm{CN}$ analyses and our laboratory technicians and student helpers for support in sample preparation. Gustav Schneiter from the LWF section is acknowledged for providing meteorological data for the experimental sites. We also thank Dr. Peter Christie of Queen's University Belfast for revising the English text.

\section{References}

Aber J.D., Melillo J.M. and McClaugherty C.A. 1990. Predicting long-term patterns of mass loss, nitrogen dynamics, and soil organic matter formation from initial fine litter chemistry in temperate forest ecosystems. Can. J. Bot. 68: 2201-2208.

Aerts R. 1997. Climate, leaf litter chemistry and leaf litter decomposition in terrestrial ecosystems: A triangular relationship. Oikos 79: 439-449.

Berg B. 2000. Litter decomposition and organic matter turnover in northern forest soils. Forest Ecol. Manage. 133: 13-22.

Berg B. and Ekbohm G. 1991. Litter mass-loss rates and decomposition patterns in some needle and leaf litter types. Long-term decomposition in a Scots pine forest. VII. Can. J. Bot. 69: 1449-1456.

Berg B. and Meentemeyer V. 2002. Litter quality in a north European transect versus carbon storage potential. Plant Soil 242: 83-92.

Berg B., Berg M.P., Bottner P., Box E., Breymeyer A., Calvo de Anta R., Couteaux M., Escudero A., Gallardo A., Kratz W., Madeira M., Mälkönen E., McClaugherty C., Meentemeyer V., Muñoz F., Piussi P., Remacle J. and Virzo De Santo A. 1993. Litter mass loss rates in pine forests of Europe and eastern United States: some relationships with climate and litter quality. Biogeochemistry 20: $127-159$.

Berg B., Ekbohm G., Johansson M.B., McClaugherty C., Rutigliano F. and Virzo De Santo A. 1996. Maximum decomposition limits of forest litter types: a synthesis. Can. J. Bot. 74: 659-672.

Berg B., Johansson M.B., Meentemeyer V. and Kratz W. 1998. Decomposition of tree root litter in a climatic transect of coniferous forests in northern Europe: a synthesis. Scand. J. Forest Res. 13: $402-412$.

Berg B., Johansson M.B. and Meentemeyer V. 2000. Litter decomposition in a transect of Norway spruce forests: substrate quality and climate control. Can. J. Forest Res. 30: 1136-1147.

Chen D.M., Taylor A.F.S., Burke R.M. and Cairney J.W.G. 2001. Identification of genes for lignin peroxidases and manganese peroxidases in ectomycorrhizal fungi. New Phytol. 152: 151-158.

Cortez J. and Bouche M.B. 1998. Field decomposition of leaf litters: earthworm-microorganism interactions - the ploughing-in effect. Soil Biol. Biochem. 30: 795-804.

Dence C.W. 1992. The determination of lignin. In: Lin S.Y. and Dence C.W. (eds) Methods in Lignin Chemistry. Springer, Berlin, pp. 33-61.

Howard P.J.A. and Howard D.M. 1974. Microbial decomposition of tree and shrub leaf litter. 1. Weight loss and chemical composition of decomposing litter. Oikos 25: 311-352.

Lee K.E. 1985. Earthworms: Their Ecology and Relationships with Soils and Land Use. Academic Press, Sydney. 
Melillo J.M., Aber J.D. and Muratore J.F. 1982. Nitrogen and lignin control of hardwood leaf litter decomposition dynamics. Ecology 63: 621-626.

Moore T.R., Trofymow J.A., Taylor B., Prescott C., Camiré C., Duschene L., Fyles J., Kozak L., Kranabetter M., Morrison I., Siltanen M., Smith S., Titus B., Visser S., Wein R. and Zoltai S. 1999. Litter decomposition rates in Canadian forests. Global Change Biol. 5: 75-82.

Perez J. and Jeffries T.W. 1992. Roles of manganese and organic-acid chelators in regulating lignin degradation and biosynthesis of peroxidases by Phanerochaete chrysosporium. Appl. Environ. Microbiol. 58: 2402-2409.

Perez J. and Jeffries T.W. 1993. Role of organic acid chelators in manganese regulation of lignin degradation by Phanerochaete chrysosporium. Appl. Biochem. Biotechnol. 39: 227-238.

Perruchoud D.O. and Fischlin A. 1995. The response of the carbon cycle in undisturbed forest ecosystems to climate change: a review of plant-soil models. J. Biogeogr. 22: 759-774.

Scheffer F. 2002. Lehrbuch der Bodenkunde. Spektrum, Heidelberg.

Swain T. and Hillis W.E. 1959. The phenolic constituents of Prunus domestica. I. The quantitative analysis of phenolic constituents. J. Sci. Food Agric. 10: 63-68

Thimonier A., Schmitt M., Cherubini P. and Kräuchi N. 2001. Monitoring the Swiss forest: building a research platform. In: Anfodillo T. and Carraro V. (eds) Monitoraggio ambientale: metodologie ed applicazioni. Atti del XXXVIII Corso di Cultura in Ecologia. Centro Studi per l'Ambiente Alpino, Università degli Studi di Padova, S. Vito di Cadore, pp. 121-134.

Trofymow J.A., Preston C.M. and Prescott C.E. 1995. Litter quality and its potential effect on decay rates of materials from Canadian forests. Water Air Soil Pollut. 82: 215-226.

Trofymow J.A., Moore T.R., Titus B., Prescott C., Morrison I., Siltanen M., Smith S., Fyles J., Wein R., Camiré C., Duschene L., Kozak L., Kranabetter M. and Visser S. 2002. Rates of litter decomposition over 6 years in Canadian forests: influence of litter quality and climate. Can. J. Forest Res. 32: $789-804$. 